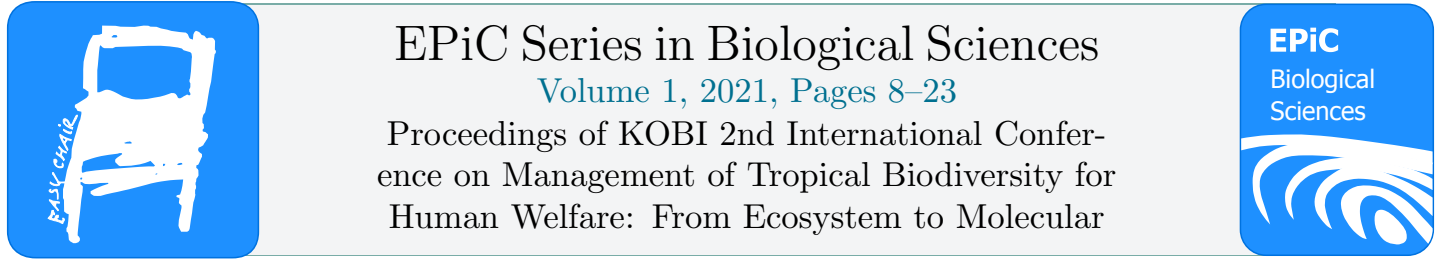

\title{
Applying Ethnobiology in Sustainable Management and Utilization of Biological Resources in Indonesia
}

\author{
Y. Purwanto ${ }^{1 *}$ \\ ${ }^{1}$ Research Center for Biology, The Indonesian Institute of Sciences (LIPI) \\ The Indonesian MAB-UNESCO Program National Committee, LIPI \\ Gedung Kusnoto Lt 4, Jl. Ir. H. Juanda 18 Bogor 16122 \\ purwanto.lipi@gmail.com, mab-lipi@mab-indonesia.org
}

\begin{abstract}
Ethnobiology has become very comprehensive with the very broad and varied topic of discussion and analysis. The application of ethnobiological data has expanded considerably and ethnobiological research has been applied to practical areas such as bioresources conservation and management, landscape management, and bioprospecting. This presentation explains the main areas of modern ethnobiological research which examines all aspects of the reciprocal relationship between human and biological resources and their ecosystem. Specifically, ethnobiology includes any studies relating to bio-resources, including how they are classified and named, how they are used and managed, and how their exploitation has influenced their evolution. The main area of modern ethnobiological investigation includes (1) Ethnobotany: study of local community knowledge systems and the overall relationship between communities and plant species diversity; ethnobotany study discussed the perceptions and conceptions of the management system of biodiversity and its natural ecosystem diversity; Ethnoecology: study of local knowledge of natural ecosystem and environmental impact of local bio-resources management; (2) Traditional Production Activities System: in this field, local knowledge of traditional production activities system includes agriculture, forestry, local technology and innovation of biological resources management and nature and environmental impact of bio-resources management; (3) Cognitive ethnobiology: a local perception of the natural world through the analysis of symbolism in ritual and myth, and their ecological consequences; organization of knowledge system through ethnotaxonomic study, etc.; (4) Material culture: a local knowledge and use of biodiversity and bio-resources products in art and technology; (5) Traditional bio-phytochemistry: a study of local knowledge and use of bio-resources for bio-chemicals, for example in pest control, poison, pungent, coloring and traditional medicine; and (6) Palaeoethnobiology/Palaeoethnobotany: a study of past interaction between human
\end{abstract}


populations and bio-resources based on the interpretation of archeobiological remains. Currently, ethnobiological data plays an important role in the conservation and sustainable use of bio-recourses.

\section{Introduction}

The diversity of perspectives in the field of ethnobiology is the greatest strength of ethnobiology. This enables us to conduct multidisciplinary, interdisciplinary, and transdisciplinary research that discusses the dynamic interaction between human knowledge systems with nature and the environment. The results of this ethnobiology study can provide benefits for the management and sustainable use of natural resources and the environment. The development of ethnobiology studies could also enhance our intellectual knowledge and abilities and can have a wider impact, especially with regards to the sustainable management of natural resources and the environment.

In more detail, ethnobiological research is to reveal and analyze the values of biodiversity scientifically through the application of science and technology; thus local knowledge and local wisdom of the local community in managing natural resources and the environment can be scientifically justified. The analysis of this study is to examine all aspects related to ethnobiology studies that result in the form of scientific evidence from local knowledge and local wisdom, new strategies, innovations, appropriate technology, and solutions for the sustainable management of natural resources and the environment. Disclosure of scientific values from local knowledge and local wisdom is expected to support the efforts of "sustainable improvement" by applying the principles of "economically feasible, environmentally feasible, socially acceptable, technologically appropriate and beneficial to the lives of the local community".

The objective of this article is to provide an update and overview of the development of modern ethnobotany research whose scope and discussion are broader and deeper. This article is also an expression of concern that ethnobiology research especially ethnobotany research in Indonesia has not developed following the latest scientific and technological advancements. Ethnobotany research in Indonesia is still limited to the identification of useful plant species. This study has not yet touched on a holistic study of the relationship between humans and biodiversity that results in a biodiversity management output that is economically, ecologically, and socio-culturally beneficial and supports the development of science and technology.

\section{Scope of Ethnobiology}

Ethnobiology is a multidisciplinary/ interdisciplinary/transdisciplinary field of study that draws on approaches and methods from both the social-cultural and biological sciences. Ethnobiology has proven a rather difficult term to define since the scope of ethnobiological studies has changed considerably throughout history. One of its more recent definitions refers to the study of the reciprocal relationships between human cultures and the natural world (Cotton, 1996). Reciprocal relationships here refer to the human perception and conception of the biological natural resources and environment, which will ultimately influence human life and behavior, while human behavior in turn influences or shapes the biological natural resources and environment. So that we can define ethnobiology as a field of science that studies the knowledge systems of a community/ethnic/tribe group concerning the biological natural resources and its ecosystem. The scope of this study covers all aspects of the life of a community/ethnic/tribe group related to the management and utilization of biological natural resources and their ecosystems. 
The field of ethnobiology studies is currently developing rapidly and in recent decades ethnobiology has become very broad and the diversity of its scholars is diverse. The application of ethnobiological data has developed rapidly and ethnobiological research has been applied in practical fields such as biodiversity management, landscape management, biodiversity conservation, biodiversity search, etc. The subject of ethnobiology is biodiversity and cultural diversity. Biodiversity and culture are enormous topics to discuss and I want to simplify from the perspective of the ethnobiological approach the relationship between humans and biodiversity (perceptions and conceptions, human praxis and impacts, and problem solutions).

The ethnobiological scope of the study has expanded enormously, encompassing the biological aspects of the number of ethnoscience field including (a) ethnobotany, (b) ethnoecology, (c) ethnozoology, (d) traditional production activities systems, (e) cognitive ethnobiology, (f) traditional classification, (g) material culture, (h) traditional bio-phytochemicals, (i) economic plants, and (j) palaeoethnobiology (Cotton, 1996; Purwanto, 2010).

In the latest ethnobiology research, we not only identify and explore local knowledge, local wisdom, and local genius of peoples/communities, but ethnobiology research must be able to discuss and express: (1) Economic aspects (related to agricultural activities, material culture (local technology), traditional biophytochemicals and ecosystem services) (2) Ecological aspects: this aspect consists of biodiversity management, biodiversity conservation, cognitive ethnobiology, and ethnoecology (3) Socio-cultural aspects: this is related to ethical values; we must be able to provide science and technology value for local knowledge about biodiversity.

\section{The Current Roles and Benefit of Ethnobiology Data}

The role of ethnobiology today is: (1) to uncover and increase the value of natural resources and ecosystems: this is one of the main objectives of ethnobiological research, which is to prove ecological value, economic value, ethical value, and intrinsic value of biodiversity; (2) to uncover and prove the scholarship of local knowledge: ethnobiological studies are expected to be able to scientifically prove local knowledge; (3) to provide support to strengthen the ability of local communities to manage natural resources and ecosystems sustainably: as we know and understand that ethnobiology studies also focus on how local communities manage their natural resources and environment so that they can be utilized for their lives. Analysis of local management of natural resources, ethnobiology studies can provide advice and input on how to strengthen sustainable management of natural resources and ecosystems; (4) to support conservation efforts of natural resources and ecosystems, as well as local culture: we can identify how local people with their knowledge preserve natural resources and ecosystems. Analysis of this study can provide support for efforts to preserve natural resources and ecosystems better and more comprehensive; and (5) to discover potential biological resources and improve their value so that these biological resources become more useful for the lives of the local communities. This study can also identify the potential of natural resources and can provide solutions to improve its quality and value.

\section{Applying Ethnobiology Data}

Ethnobiological data, which is the result of a holistic and comprehensive analysis of the human relationship with biodiversity, will be able to support various aspects of community life and can be applied to the whole life of the community as follows. 


\subsection{Support biodiversity development to increase prosperity and national development}

Ethnobiology studies must be able to provide support biodiversity development to increase prosperity and national development. As we know that biodiversity is very useful for human life, which is: used for food, health, fiber, energy, germplasm, etc. The ethnobiology study is not only identified the uses of bio-resources, but the ethnobiology study must be able to support biodiversity development to increase the value of each usage of bio-resources.

The biodiversity management in conservation and surrounding areas should not be aimed solely to maintain and protect biodiversity in these areas, but it should also emphasize the integrated management approach of the landscape ecosystem in the conservation area and the surroundings. This landscape ecosystem approach concept needs to be implemented so that the advantage may be useful for the management of the areas and the socio-economic and cultural interests of the surrounding communities. Ethnobiological research data can support management efforts in the conservation and surrounding area in a sustainable manner. For example, integrated area management through an ecosystem landscape approach. In the management of biodiversity in an area through a landscape approach, it is not only based on the integration of several types of ecosystems but also involves the parties and communities in the region. The function of ethnobiology studies is to express the knowledge of the community and parties in managing the area. Local knowledge is the basis for regional development and management.

Management of the area based on local knowledge and local wisdom can secure the surrounding forest area. For example, the management of the traditional conservation area of the Dayak Kenyah people is called "Tanah ulen". Tanah ulen area has a function not only as a conservation area and balancing the ecosystem in the community area, but also has a function as a reserved area for community needs during times of famine. For example, this area is used as a hunting area, gathering and extracting non-timber forest products during times of food shortage or in times of preparing for large traditional ceremonies that require food and other ritual materials. This area is also used as a gathering area for types of food plants, medicinal substances, poisonous substances, spices, coloring agents, and equipment (Purwanto et al., 2011). In expressing the function and role of the tanah ulen it is effective if it is carried out with ethnobiology studies.

This study can also provide benefits in support of food programs through the disclosure of species of local food plants and species of potentially food-producing; health programs through the disclosure of species of medicinal plants as new medicinal ingredients; energy program through the disclosure of ethanol-producing biodiversity species; biodiversity conservation programs through disclosure of traditional conservation systems; program for the discovery of species of biodiversity with economic potentials, such as producing dyes, poisons, anti-poisons, preservatives, seasonings, spices, adhesives, and others

\subsection{Support the development of applied science and technology: agriculture, biotechnology, ecology, and the other applied sciences}

The ethnobiology data is a piece of basic information or basic data for applied science and technology development. For example: in agriculture, we must able to provide data about the local practice and also cultivated variety diversity as basic data for breeding; also basic data for increasing the quality of the cultivated variety of cash crops. In traditional medicinal, the ethnobiology study can provide basic data of the bio-resources potency based on the ethno-direct sampling method, so the ethnobiology data can be the basis for further development. The LIPI and Kyoto University Study in 2008-2009 on the potential of biodiversity in the Giam Siak Kecil-Bukit Batu Biosphere Reserve in Riau found a species of meranti bakau (Shorea uliginosa), which has high ethanol content (> $20 \mathrm{mg} / 100$ $\mathrm{mg}$ xylem). Should any wood species be recommended as bio-ethanol raw material as the result of these 
researches, it needs to be cultivated in bio-ethanol forest estates in a considerably large area. It is to enable the installation of bio-ethanol production.

Research on local conservation systems in Indonesia summarized in the book Natural Sacred Sites: The Role of Culture in Conservation of Biodiversity (Soedjito et al., 2009) shows that the local community/ethnic/sub-ethnic groups in Indonesia have local wisdom in preserving biodiversity and the environment. Soedjito and Purwanto's (2003) research on local conservation in Timor Island shows that the sacred site of indigenous peoples in this region has a value of biodiversity and ecosystem conservation.

\subsection{Reveal and prove local knowledge into useful and valuable knowledge}

Ethnobiology studies can also provide evidence of local knowledge about the management of biological resources, whether they have scientific evidence or not. For example, the research we conducted in the Baliem Valley was able to prove that the agronomy cultivation of Dani sweet potato plants can be proven agronomically. Dani people can adapt the cultivation of sweet potato plants in three different ecosystem types, namely swamp area, flat area, and hilly area. The three cultivation systems from ecological aspects are very environmentally friendly (Purwanto, 1997). Likewise, the people on Yamdena Island, their knowledge of spatial planning by their roles and functions, can provide for their living needs (Purwanto et al., 2004). Timorese people in NTB have local conservation knowledge that can preserve the diversity of local species and the ecological functions of the local conservation area, for example, maintaining water sources, protected areas for wildlife in the area, and becoming a water catchment area (Soedjito and Purwanto, 2003). There are many more examples of local wisdom that has conservation values, economic values, and socio-cultural values, for example, Conservation concept of Leuweung kolot by the Kasepuhan community on Mount Halimun (Adimihardja, 2009); the Mandala area of the Badui community in Banten (Iskandar, 2009); Lubuk Larangan on communities in Mandailing Regency Natal (Lubis, 2009); Fatnik concept of the marine biodiversity conservation of Padaido Island community, Papua (Kaber et al., 2009); Wakunmo and Wussama of the sacred area of the Dani community in the Baliem Valley (Purwanto, 2009); Mophilolonga Katuvua: Conception of the Toro community in maintaining the preservation of forest resources (Golar Baso, 2009); Tanah Ulen and the natural sacred concept of the Dayak Kenyah community at Setulang, Malinau District (Soedjito, 2009); and others. The natural sacred sites of these local community/tribal groups/ethnic have conservation (ecological), socio-cultural, and economic values for their community members. Local conservation areas are also evidence of land tenure, a source of necessities of life during a famine, protecting the area, and the function of ecosystem services.

\subsection{Reveal the development of local knowledge about medicinal plants and prove its usefulness scientifically}

The ethnobiologist should be able to prove the science of local knowledge. In ethnomedicine study, we should be able to prove the local knowledge of medicinal plants in modern medical science; we analyze the compound of the local medicinal plant and prove the usefulness, etc. There are three ways to reveal the medicinal properties of bio-resources: first through the ethnic-direct sampling method, second through random sampling method, and third through phylogenic targeting sampling method (Purwanto and Munawaroh, 2002). For example study on the potential of the Simaroubaceae family as anti-malaria that based on the ethnic-direct sampling method. This study is not only identified and noted the local knowledge, but this study is also proving this plant as anti-malaria. Also, the study on lecithin and omega-3 content of labi-labi (Amyda spp.) in the Giam Siak-Bukit Batu Biosphere Reserve proves that this species has potential as a source of lecithin and omega-3 (Agusta, 2011). Lecithin and omega- 
3 fatty acids are highly needed by the body but not produced by the human body itself so it must be sourced from the outside. Omega 3 fatty acids have a very important role in maintaining brain function and for normal growth and development of children. In addition, omega 3 fatty acids are also useful for reducing inflammation, helping to prevent the risk of chronic diseases such as heart disease, cancer, and rheumatism. Omega 3 fatty acids consist of 3 main types of fatty acids, namely alpha-linolenic acid (ALA), eicosapentaenoic acid (EPA) and docosahexaenoic acid (DHA) with potential sources of various types of fish (Annonim, 2009).

\subsection{Reveal local cultivar of food plant that has high production, resistance on pest and disease, etc.}

The ethnobiological study also should be able to prove the food plant diversity and give basic data for future research in plant breeding. Information about the rich diversity of a local variety of cultivated plants can be used as a genetic source for plant breeding efforts. The results of ethnobotany research in the Dayak Benuq area by Hendra (2009) identified more than 50 local cultivars of rice and glutinous rice and of course, the diversity of these rice cultivars is very beneficial for rice plant breeding as a genetic source.

\subsection{Able to be a basic instrument to help solve problems that are handled globally}

Several types of research in Ethnobiology, especially in food plant in Africa, can help resolve the food problem in this area. Ethnobiology can be able to reveal the local food source from the local community and then improving the quality and quantity of this food plant. For example, a study on barley species.

\section{The Modern Ethnobiology Area}

The modern ethnobiology area is consisting of several major fields of the investigation that are distinguished here: ethnobotany, ethnoecology, traditional agriculture, cognitive ethnobiology, traditional classification, material culture, traditional biochemistry, and paleoethnobiology. Each of these areas of ethnobiological study is drawn from the theory and techniques of a range of established disciplines. For example, an ethnopharmacological study of the traditional herbal pharmacopeia might require anthropological and medical assessments of the ethnomedicinal system, the taxonomic skills of botanist, the linguistic techniques of ethnotaxonomists and etymologists, and the analytical expertise of phytochemistry, natural products, and pharmacognosists (Cotton, 1996; Purwanto and Munawaroh, 2002).

\subsection{Ethnobotany}

The scope of Ethnobotany modern has become extremely broad that constitutes a diverse field of study, which examines all aspects of the reciprocal relationship between plants and peoples. It is, by necessity multidisciplinary, interdisciplinary, and trans-disciplinary in its approach and draws from a broad range of the subject areas: (a) plants use, (b) local knowledge on ecosystem, (c) local/traditional agriculture system, (d) cognitive ethnobotany, (e) material culture (plants), (f) traditional phytochemistry, (g) medicinal plants, and palaeoethnobotany (Cotton, 1996) and (h) traditional classification (Purwanto, 2010). So in ethnobotany studies, researchers must be able to show the overall relationship between local communities and living natural resources and their ecosystems, including 
the management of plant natural resources and their ecosystems. Ethnobotany researchers must not only show and discuss local knowledge concerning the management of plant natural resources and their ecosystems, but ethnobotany researchers must be able to demonstrate the scientific knowledge of local communities in managing plant biological natural resources.

Ethnobotany studies today have an extraordinary appeal and have increased dramatically in recent years. The search for a new drug or new medicines by the pharmaceutical industry has turned to plant natural products and ethnobotanical studies as the first step of bioprospecting. These studies are making a valuable contribution to the cataloging of biological diversity and hence to the conservation of endangered ecosystems and the human societies which depend upon them (Cotton, 1996). The application of ethnobotany studies will provide results about the economic value, ecological value, ethical value, and intrinsic value of the diversity of plants and their ecosystems.

\subsection{Ethnoecology}

The scope of ethnoecology modern is the study of human knowledge, perception, classification, and management of natural environments. In the Anglo-Saxon countries, this term of ethnoecology is not known well, because they know this area as a human ecology area. The francophone country said that human ecology is related to human health. But the important is how they analyze this domain. The francophone country with "savoir-faire" and Anglo-Saxon with "know-how". What does it mean? In ethnoecology study, we have to necessary to analyze holistically all the related data. We have to analyze data with the question "known how" or "savoir-faire".

How do we study Ethnoecology? There are several steps in conducting ethnoecological studies, namely:

(a) We must be able to reveal in detail the description of the actual conditions of the region we study

(b) Reveal the "corpus" of the community in the area under study by reconstructing the perception and conception reconstruction (corpus) of the local community on natural resources and environment or often termed a "knowledge system".

(c) Reveal the "praxis" of the local community that is related to production activities in managing biological natural resources and their ecosystems

(d) Ecological excellence on praxis (including human impact and adaptation technology of local communities

(e) Solution problems and sustainable development models on natural resources and ecosystem management.

\section{The purpose of ethnoecology data related to local conservation and biodiversity}

Each community group has local knowledge and technology to conserve the richness of biodiversity in their area. They have management institutions; they have legal aspects and norms to manage this area. The results of Purwanto and Soedjito's research (2003) show that local communities have a local knowledge system in managing areas both for production, for housing, and conservation areas. From the results of the analysis of the local community conservation area shows that the local conservation area in the form of a sacred area or an area whose management is customarily managed by the community has several advantages including:

(a) Have high conservation value and biodiversity richness and ecological roles (habitat of biodiversity species, gene pool, and indicator site)

(b) Conservation dimensions that more sustainable and more public awareness demonstration in environmental education.

(c) As a model of area management based on local knowledge or local wisdom

(d) Protection and maintain local culture

(e) Manifested culture and cultural diversity

(f) Has the value eco-tourism (biodiversity and culture)

(g) Having religious value as sacred and holy 
This figure below is an example of the ethnoecology study that Toro people descript their environment very well. They devised their environment based on their function and their need. They devise the area for conservation, for reserve area, for settlement, for production activities, etc. Through the division of their environment, they can arrange the need for daily life, for reserve when the time of famine, for conservation area (source of water and ecosystem services). They also use for settlement (villages and housing), for a sacred site, etc. With this local environmental management, we can learn about the local strategy in the food provision, food security, and also daily life need. This local concept has scientifically proven to support the sustainable development program.

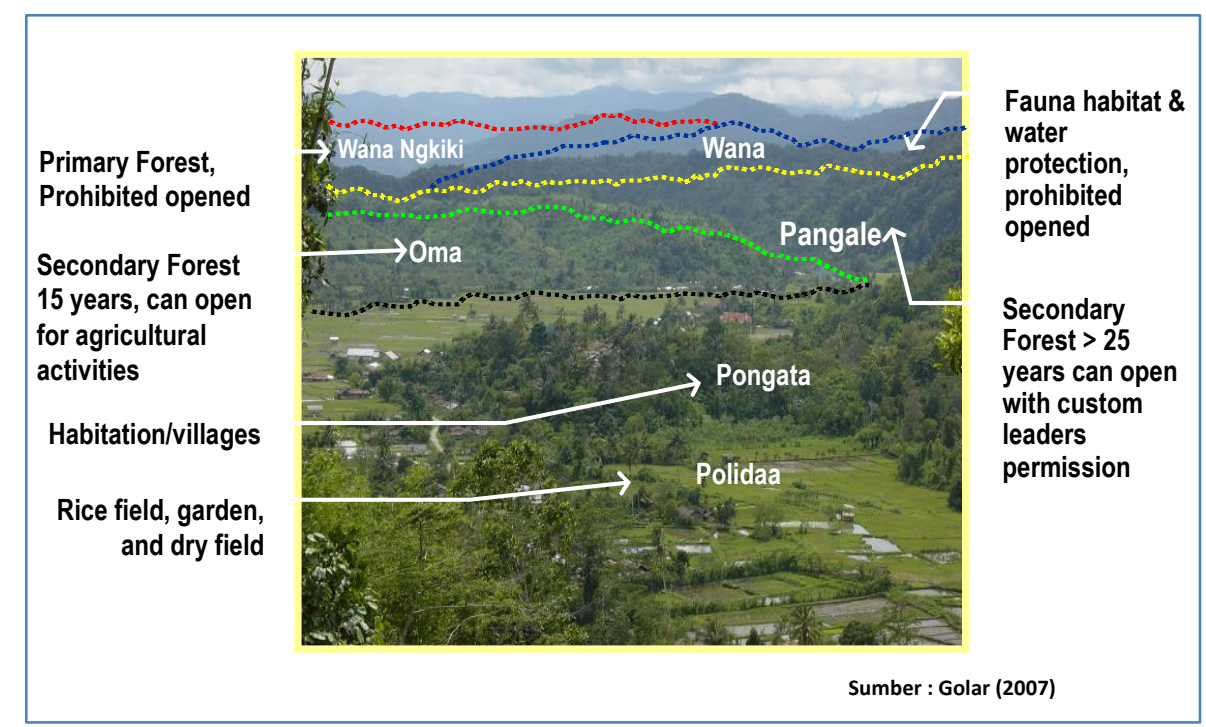

Figure 1: The spatial arrangement of the Toro community in Lore Lindu Biosphere Reserve, Central Sulawesi (Golar, 2007)

The spatial arrangement of the Badui community in Banten Province based on sacred values and functions (Iskandar, 2007). The detail of the spatial arrangement of Badui through a zoning system like the zoning system of the biosphere reserves concept, namely the core area, buffer zone, and transition area. The Badui zoning system is as follows: (1) Sasaka domas: area more sacred and this is like the core area of a biosphere reserve. This area is protected and respected not to be disturbed and damaged. Only a few members of the community are allowed to enter this sacred area; (2) Tangtu: this area is also sacred but less sacred than sasaka domas, related with "buffer zone", as a buffer of "sasaka domas" area; and (3) Panamping area: This area is less sacred and as an area for production activities and at the same time as an area to be a filter for outside influence.

\subsection{Local knowledge on agriculture}

Local community relies on their lives with agricultural activities and the availability of biological natural resources in the region. The local community has the technology in developing biological resources, especially in the context of fulfilling their sources of life. In connection with agricultural activities of local communities, we can learn about the following aspects: (a) local adaptation technology on plant cultivation process; (b) local knowledge on species and cultivar of a plant; (c) local knowledge on biophysical aspects (agriculture) like pest and diseases, soil, climate, etc.; (d) local knowledge on the agricultural system: shifting cultivation, agroforestry, plantation, pastoral farming, etc.; and (e) innovation and development. What do we learn from this knowledge? We can provide scientifically local knowledge of local knowledge on agriculture activities, we learn several local 
technology and strategy adaptation, they have never experienced hunger, and they can self-sufficient in food.

Purwanto's (1997) research on the traditional agricultural knowledge of the Dani people in the Baliem Valley revealed a fairly sophisticated sweet potato cultivation system that was adapted to environmental conditions. They developed a system of cultivating sweet potato in swampy areas, flat areas, and hillside areas. From the agronomy study, the three systems developed by the Dani-Baliem community can be held accountable for their faith and are environmentally friendly.

Besides that, the sweet potato cultivation system of the Dani-Baliem community is also an area for the conservation and development of local germplasm of sweet potato. One garden area of sweet potato cultivation around 5-10 ha, found about 100 local cultivars, and each species has its uses, for example, cultivar as the daily main food, food during traditional ceremonies/ritual, food for the sick, baby food, and pig food. The diversity of local sweet potato cultivars found in the Baliem Valley region is a genetic resource of sweet potato breeding. Besides that, in this area, we also find the diversity of local cultivars of cultivated plants, such as cassava (6 cultivars), taro (17 cultivars), bananas ( $>22$ local cultivars), winged beans ( 6 cultivars), etc. (Purwanto, 1997). Likewise, local communities on Yamdena Island, Southeast-west Moluccas have also a diversity of cultivars of the plant including Dioscorea alata (13 local cultivars), Ipomoea batatas (4 local cultivars), Manihot esculenta (4 cultivars), Dioscorea esculenta (8 cultivars), Ipomoea batatas (4 local cultivars), Colocasia esculenta (12 cultivars), and others (Purwanto et al., 2004)

\subsection{Cognitive ethnobiology}

Cognitive ethnobiology studies have been carried out by researchers who have anthropological and social science backgrounds because this study reveals the socio-cultural value of local communities concerning the management of biological natural resources and their ecosystems. Cognitive ethnobotany research is focused on local community perception and conception of natural resources and environments through symbolic, mythic, totem, ritual, and ecological consequences. Cognitive ethnobiology is grounded in cornerstones of cognitive anthropology, namely ethnoscience and ethnosemantic. This study adopts the understanding of human culture as a generative system of knowledge that can be examined formally, through linguistic modes of analysis that obviate existing units or categories of measurement (Nolan and Stepp, 2013). This study identifies the constituents of cultural domains, such as local knowledge organizations through ethno-taxonomy given and local classification of natural resources (identification, local name/naming, and classification), the local name of edible plants, and semantic dimensions that define the structure of these domains, such as the gradient of hot and cold, or bitter and sweet. Rules for naming and classifying the living world continue to be elicited by cognitive ethnobiologist in their efforts to examine human knowledge of indigenous flora and fauna. Example research of Freidberg (1990) on "Le Savoir Botanique des Bunaq, percevoir et classer dans le Haut Lamaknen, Timor, Indonesie” .

Cognitive ethnobiology encompasses multiple theoretical approaches to elicitation and interpretation of ethnobiological information in the context of ethnographic fieldwork (Nolan and Turner, 2011). According to Nolan and Stepp (2013), the fundamental principle guiding cognitive ethnobiology is the conviction that ecologic information is encoded in human collective knowledge. Language has an important role as the medium of human communication and expression, constitutes the basis for semantic analyze involved in ethnobiological ethnography. So that the approach can be through a combination of qualitative and quantitative data collection techniques because this research not only discovers what people know about their biotic world but also how this knowledge is meaningfully translated through everyday experience. The cultural knowledge of living things and the accompanying qualitative understanding, including symbolic and ritual thoughts in everyday life and throughout the calendar season, is used by ethnobiology studies to assess condition and citation real problems with the applied anthropological component. Cognitive ethnobiology discusses topics that 
have great practical significance related to conservation biology, preservation of indigenous ecological knowledge systems, and more broadly the maintenance, conservation, and revitalization of traditional languages, arts, and folklore.

\subsection{Popular classification/traditional classification}

Popular classification means the conceptualization and classification of plants and animals by individuals or groups of people (ethnic or ethnic groups). To facilitate understanding of the popular classification system or local classification, we discuss three main aspects in the popular classification system, namely identification, naming, classification in a sequence following the reference system. These three aspects of the popular classification process are very important to be able to understand and express the classification characteristics of local community groups. In general, local people use different characteristics of plants in their surroundings to arrange the diversity of plant species (plant world) into a classification system that is easy to understand not only for community members but also for other communities.

Methods and steps for studying popular classification are as follows: (1) inventorying the local knowledge of people learned about the plant world; (2) grouping various types of plants based on plants that have the same basic name (in the traditional classification referred to as series); (3) differentiating plant species that have different determinants or information; (4) grouping types of plants that have different basic names and looking for the meaning of each name, along with specimens of these plant types. In Indonesia, Claudine Friedberg since 1962 researched the plant classification system of the Bunaq community in Lakmanen, East Timor Island, Friedberg researched various aspects including traditional farming systems, local botanical knowledge systems, biological resource management systems, and the surrounding natural environment, customs and various rituals and traditional classification systems for biological resources. Friedberg (1980) analyzed in-depth the traditional botanical vocabulary system in naming plant species, describing it hierarchically in traditional classifications and compiling the key to local determination of the Bunaq community on the diversity of plant species and their environment.

Although the study of ethno-taxonomy has not perfectly provided specific terminologies such as modern taxonomy, the study of traditional naming and classification systems can help reveal people's perceptions of biological resources. The disadvantage of ethno-taxonomy is the lack of consistency in the naming and classification system based on the mention of a type of plant. This is exemplified in the general naming and classification knowledge system that can be extracted from the general members of the community, but for naming and classification that is specifically obtained from personnel (local expert) from local community members. Besides, sometimes it is difficult for us to explore the reasons why a community group is doing a certain technique or naming a type with a certain name. For example, the Dani-Baliem community gives the name of their former village as "olinmo", giving the name olinmo to have the following meanings: $o=$ wood; cf. $=$ Alphitonia excels $a($ A incana) and $m o=$ place. The former village is called olinmo because generally the fertile former village is overgrown by the dominance of wood cf (Alphitonia excelsa) (Purwanto, 1997). Another example is the Tanimbar-Kei community dividing Tanimbar-Kei Island into two parts namely nuhuten and nuhuyanat. If we ask why the island is divided into two parts, they give reasons because of tradition. The division of islands into two parts has ecologically meaningful reasons. Besides this division prevents the occurrence of garden concentrations in a certain area, it is also able to maintain the presence of various types of plants from damage caused by the shifting cultivation system they practice (Purwanto, 2003).

\subsection{Material culture in ethnobiology}

The material culture is object studies that a relatively new field of academic inquiry, commonly called the study of material culture. Material culture is traditional knowledge and use of plants and 
plants products in art and technology (Cotton, 1996). Material culture research seeks to understand society or community, both past, and present, through careful study and observation of the physical or material objects produced by that community. Material culture study refers to local knowledge related to the physical objects, resources, and spaces that people use to define their culture. Studying physical objects (material culture) from a community's culture can give us a better understanding and appreciation for the complex life between local people who interact with these cultural objects. Studying the material culture of a community group can give us a clearer insight into the nonmaterial culture, which includes community ideas, beliefs, habits, and values. Material culture as the total range of objects produced by a particular society including functional terms such as tools, shelters, and clothing as well as more decorative arts and handicrafts (Bahru et al., 2012).

This ethnobiology material culture study in Indonesia reveals the local community's knowledge in local technology of physical object including (1) study on local knowledge technology and art diversity (material based of plant natural resources); (2) study on the plant diversity used as local art and technology; (3) transfer technology of local art and technology (past, present and next-generation); (4) study on social, economy and ecology roles of material culture; and (5) innovation and development.

The study of cultural material in Indonesia has become very important due to changes in Indonesian society that intersect with the industrial world and the decline of natural resources. Biodiversity has a very fundamental role in the cultural material of local communities in Indonesia. Biodiversity is part of the products in the material culture of the Indonesian people. Loss of biodiversity as a material maker in the material culture (technology and art) of the community will influence their lives. It is hoped that material culture studies can provide support in the sustainable management of biodiversity.

\subsection{Traditional biochemistry}

Many biodiversity species produce chemicals, which are used in the traditional daily life of traditional community and industry. Traditional phytochemistry is traditional knowledge and use of plants for plant chemicals (Cotton, 1996), for example in pest control, color, medicine, spices, seal, pigment, etc.

Research on traditional biochemistry is very important because the chemical characteristics of biodiversity have a very important role in the lives of traditional communities and industrial interests. Besides that, chemicals from biodiversity also have benefits for traditional community life but are also very important for industries such as the vegetable oil industry, lubricants, paints, varnishes, dyes, latex (rubber), soaps, stimulants, poisons, and therapeutic agents.

Traditional biochemistry now focuses on local knowledge of biodiversity utilization as a chemistry material that used as well-being: (a) Material nonmedicinal: coloring material, poison, and non-poison, adhesive, spices, pungent agent, flavoring agent, etc.; (b) Medicinal material; (c) Local technology on production of non-medicinal and medicinal; and (d) Management, use, and conservation in term of sustainable development. As an example, the use of chemicals contained in plants traditionally by the local community has long been known and now has become a processed product that has a high economic value in the market. For example species of henna (Lawsonia inermis, Lytraceae) which used to be commonly used by Greek and Egyptian women as hair dyes, now dried henna leaves have been sold in the form of brown powder and used as hair and body dyes. This dye is now commonly used as a hair dye in modern salons. Now, the use of natural dyes not only functions in the pharmaceutical industry but also various other needs in society. Its use can be found in the textile and food industry, the fiber in the handicraft industry, in the ceramic or woodcraft industry, body tattoos, and hair dyes. People use plant material to paint the skin, to ornament clothing, or decorate the skin for religious ceremonies or warfare and disguising purposes.

Pigments can be isolated from various types of plants and various parts of plants, for example from the bark, leaves, seeds, fruit, and other parts. Of the 183 types of plants that have been used as dyes (See Purwanto, 2010), coloring agents can be isolated from 21 parts of plants. The bark is the most used 
part about $31.7 \%$, then followed by leaves (16.94\%) and flowers (12.2\%), fruit (9.29\%), wood (9.29\%), roots $(7.1 \%)$, young shoots $(3.83 \%)$, seeds $(2.73 \%)$, and other parts $(11.52 \%)$. The color produced from the isolated material has a high variation, from 183 species that have been used as coloring agents, 13 colors are found, namely yellow, black, red, brown, green, blue, orange, beige/pink, gray, purple (including violet and indigo), white, orange and beige. Yellow is the most color produced, followed by black, red, brown. The ten most commonly produced colors are yellow $(27.87 \%)$, black $(19.67 \%)$, red $(16.94 \%)$, brown $(9.84 \%)$, green $(6.56 \%)$, blue $(6.01 \%)$, orange $(4.92 \%)$, pink/beige $(3.83 \%)$, shade group $(2.73 \%)$, gray $(2.2 \%)$, other colors $(2.2 \%)$ (see Purwanto, 2010).

Research on natural dyes from biodiversity at this time, besides to identifying the type of color also conduct analytic studies about the quality of colors, how to produce them: extraction techniques, application techniques, color characterization (color measurement results, type of pigment, quality of coloring, mordant effect if any).

\subsection{Palaeoethnobiology (Palaeoethnobotany)}

A study on the past interaction between the human population and biodiversity-based on archaeology remains. We can reconstruct of historical and evolution of human activities in a certain area, human impacts, and evolution of biodiversity especially plant from time to time. Recent paleoethnobotanical research addresses issues that stand out in this archeological sub-discipline such as the origins of agriculture, the use of resources, the reconstruction of the environment, anthropogenic environmental changes, political-economic changes, plants crop cultivation and production, crop processing, consumption (diet), and site precipitate. Some methods of identifying plants for macrobotanic remain including morphology using a light microscope, with histology scanning electron microscopy, and statistics. The study of microbes' remnants has developed rapidly and now includes pollen, phytoliths, chemistry, and molecular analysis.

The field of palaeo-ethnobotany studies in Indonesia has not been well developed and even today it is very rare to carry out research activities in this field. The results of this palaeoethnobotany study are very useful as a basis for regional development by providing information on the relationship between the community and natural resources in the past up to now. For example, the results of the study Haberle et al. (1993) who conducted a study on Environmental Change in the Baliem Valley, Montane Irian Jaya, Republic of Indonesia, gives an image of the evolution of ecosystem changes and the relationship of the Dani people in the Baliem Valley with the environment since 6,500 until 7,000 years ago.

\section{International Appeal to the Ethnobiology Data}

The world community ethnobiology has great attention on three important matters for ethnobiological research purposes, namely: (1) Identify of useful plant species, especially for commercial value (economic value). The researchers want ethnobiology to find new species/cultivars of cultivated plants and non-cultivated plants that have high economic potential through "ethno-direct sampling method", for example, some species of sap/resin producing plants, oil-producing, and bioenergy sources. An example is the disclosure of the potential species of meranti bakau (Shorea uliginosa) as a source of ethanol raw material; (2) Local technology on conservation of plant resources and habitat. The results of research in several ethnic groups in Indonesia, for example, the Dani tribe in the Valley of Baliem (Purwanto, 2002), the Dayak Kenyah community (Purwanto et al., 2011), the Toro community (Golar, 2007; Purwanto et al., 2013), the Badui community (Iskandar, 2007) and others (Soedjito et al., 2009), know about conserving living natural resources through spatial distribution and one of them is a sacred area and/or protected area because of custom. This sacred area turns out to be safer and more sustainable compared to modern conservation areas because people respect the sacred area more; and (3) obtain germplasm conservation of cultivated plants for breeding and bioprospecting. 


\section{What has been done with ethnobiology data?}

Ethnobiology data can be used to support the implementation of regional development by presenting data on the values of biodiversity, ecological values, ethical values, and intrinsic values of biodiversity. In addition, ethnobiology data also presents a system of local knowledge, local wisdom, and local genius in the management of the area that can be used as a basis planning to support sustainable regional development. Furthermore, ethnobiological data can present the socio-cultural conditions of the community in managing biodiversity and its ecosystem. Thus the local community knowledge can facilitate the development of the region sustainably. In the context of the development of sciences and technology and the development of finished products of new medicine, ethnomedicinal data becomes the basis and important source in the development and discovery of the new drug. Disclosure and development of modern drug products based on the local knowledge of the community "Ethnodirect sampling method" have resulted in the majority of discoveries of new types of drugs today.

Based on observations in the publication of research results of medicinal plants, more than $80 \%$ only revealed the use of the diversity of plant species as medicinal ingredients and about $20 \%$ in the form of phytochemical analysis of medicinal plant types that have been known as medicinal ingredients. Most research on medicinal plants in Indonesia ignores the first step, namely the analysis of the traditional knowledge system of a group of people on traditional medicine that utilizes the diversity of plant species. In addition, research on these medicinal plants very rarely reveals the techniques of treatment and methods of compulsion as carried out by the community. The traditional knowledge of the community greatly supports phytochemists, phytopharmacologists, and other chemists in their efforts to find new compounds. Analysis of a type of medicinal plant and the right ingredients from local medicines can facilitate phytochemical analysts in identifying new compounds of active ingredients of medicines.

Ethnobiology data can also be integrated with sustainable regional development strategies through: (a) Landscape ecosystem approach: The ethnobiology data especially ethnoecology data must be able to support sustainable environmental management. The ethnoecology study can determine local knowledge of natural resources and environment management, and support the adaptation strategy, which was developed from the local potential. In the landscape ecosystem approach, the development of the region is not enough just to integrate various types of ecosystems, but it also needs to be combined the role and function of stakeholders in the landscape to be developed. For this reason, local community knowledge is important in managing the area using a landscape approach.

(b) Multi-stakeholder approach: Each stakeholder has a role in the development of biological diversity resources and ecosystem in the area, for example, the central and local government represented have a role to determine the program, policy, budget, and regulation; Research Institute and Universities have roles in research and development, education for sustainable development, innovation and applied technology; and NGOs, Private Sector and Community have roles as a facilitator, funding and programs implementation. A multi-stakeholder approach can create a situation or rule that allows all stakeholders to get involved and benefit from human activities of sustainable development.

(c) Local community involvement: Ethnobiology study can determine the local potential to be able to be the basis for determining the role of the local community. Local community roles through action planning on community development and conservation of natural resources and ecosystems. This approach can also create a situation or rule that allows human potential (all stakeholders) to grow together.

(d) Science, technology, and innovation: Local knowledge, local wisdom, the local genius of the communities is the source of science, technology, and innovation for scientists. The ethnobiology data is about science, technology, and innovation in the management and development of bioresources. The roles of scientists are very important in bio-resource development especially to improve the bio-resource value (economy, ecology, and ethical value). To achieve sustainable 
development in bio-resource management, we need supports of science and technology that involve various disciplines to find new methods or a new strategy or innovation or problemsolving to use sustainable natural resources. For your note that science and technology aim to improve continuously the methodology of the bio-resources development program and the sustainable use of bio-resources.

(e) Sustainability: Create a situation or rule that allows all aspects of sustainable human activities economically, socially, and ecologically. No matter how good the planned development program, available of capital and financing, and have the support of the parties and others, but if all elements in the region are not set up in the context of sustainable development, then do not expect sustainable development programs can be successfully implemented. As an indication that sustainable development is successful if there is "continuous improvement". What is implemented by continuous improvement is by implementing/implementing the principles of "economically feasible, environmentally viable, socially acceptable and technologically appropriate".

\section{Enhancing the Role of Ethnobiology Study}

In closing this article, I want to say that ethnobiology data has an important role in expressing the potential and advantage of the region both from the socio-cultural, economic and biological aspects as well as the physical aspects, however, we continue to strive to enhance the role of ethnobiology studies in developing a region. Especially for sustainable development that involves all stakeholders and the joints of community life and the wealth of its natural resources. The following are very important things that should be sought to enhance the role of ethnobiology today, namely: (1) the central point of Ethnobiology study is the ethnic and bio-resources; (2) ethnobiology should be able to actualize themselves; (3) ethnobiology can provide a source of data to support applied science and technology; (4) ethnobiology can reveal local knowledge that useful and valuable by linking the actual problem; (5) ethnobiology can provide support for increased competition for local products, biodiversity conservation efforts, environmental functions and support for local property rights; and (6) ethnobiology pioneering scientific proof of local knowledge.

Finally, I suggest that conducting ethnobiology studies should have broad thinking (multi-aspect), a trans-disciplinary approach, working in detail, and far-sighted (visionary).

\section{Reference}

Adimihardja K. 2009. Leuweung Titipan: Hutan Keramat Kasepuhan di Gunung Halimun., dalam Soedjito et al. (2009) Situs Keramat Alami: Peran Budaya dalam Konservasi Kenakeragaman Hayati. In Bahasa. Yayasan Obor dan LIPI.

Agusta A. 2011. Kajian kandungan nutrisi, lesitin dan omega-3 pada labi-labi lokal. In Bahasa. Laporan Penelitian Pusat Penelitian Biologi-LIPI dan Program MAB Indonesia.

Anonim. 2009. Omega-3 fatty acids. www.umm.edu (University of Maryland Medical Center Website). 27 March.

Bahru T, Asfaw Z, and Demissew S. 2012. Knowledge on Plant Species of Material Culture (Construction, Traditional Arts \& Handicrafts) used by the Afar \& Oromo Nations in and Around the Awash National Park, Ethiopia Global Journal of HUMAN SOCIAL SCIENCE Geography \& Environmental GeoSciences 12(11)

Boedhihartono. 2009. Tanah Toa, Kajang, Bulukumba, Sulawesi Selatan dalam Soedjito et al. (2009) Situs Keramat Alami: Peran Budaya dalam Konservasi Kenakeragaman Hayati. In Bahasa. Yayasan Obor dan LIPI. 
Golar B. 2009. Mophilolonga Katuvua: Konsepsi Masyarakat Adat Toro dalam Mempertahankan Kelestarian Sumber Daya Hutan. dalam Soedjito et al. (2009) Situs Keramat Alami: Peran Budaya dalam Konservasi Kenakeragaman Hayati. In Bahasa. Yayasan Obor dan LIPI.

Haberle SG, Hope GS, and de Fretes Y. 1991. Environmental Change in the Baliem Valley, Montane Irian Jaya, Republic of Indonesia. Journal of Biogeography (18): 25-40.

Hendra M. 2009. Etnoecologi Perladangan dan Kearifan Botani Lokal Masyarakat Dayak Benuaq di Kabupaten Kutai Barat, Kalimantan Timur. In Bahasa. Disertasi Doktor Institute Pertanian Bogor. Sekolah Pasca Sarjana IPB.

Iskandar J. 2009. Pelestarian Daerah Mandala dan Keankeragaman Hayati oleh Orang Badui. dalam Soedjito et al. (2009) Situs Keramat Alami: Peran Budaya dalam Konservasi Kenakeragaman Hayati. In Bahasa. Yayasan Obor dan LIPI.

Kaber Y, Bawole R, and Mentansan G. 2009. Fatnik Konservasi Sumberdaya Hayati Laut Masyarakat Kepulauan Padaido, Papua. dalam Soedjito et al. (2009) Situs Keramat Alami: Peran Budaya dalam Konservasi Kenakeragaman Hayati. In Bahasa. Yayasan Obor dan LIPI.

Lubis ZB. 2009. Lubuk Larangan: Revitalisasi Situs Keramat Alami di Kabupaten Mandailing Natal. dalam Soedjito et al. (2009) Situs Keramat Alami: Peran Budaya dalam Konservasi Kenakeragaman Hayati. In Bahasa. Yayasan Obor dan LIPI.

Nolan JM and Tunner N. 2011. Ethnobotany: The Study of People Plants Relationships. In Ethnobiology. E. Anderson, D. Perrsall, E. Hunn, and N. Turner (eds.) New York: Wiley-Blackwell.

Nolan JM and Stepp JR. 2013. The application of Cognitive Ethnobiology to Environmental Education. In Kopnina, H. (ed.). (2013). Anthropology of Environmental Education. Nova Science Publishers.

Purwanto Y. 1997. "Gestion de la biodiversité: Relation aux plantes et dynamiques végetales Chez Les Dani de la vallée de la Baliem en Irian Jaya, Indonésie". Thèse de Doctorat, Université Pièrre et Marie Curie. Paris.

Purwanto Y. 2002. Gestion de la biodiversité: Relations aux plantes et dynamiques végétales chez les Dani del la vallée de la Baliem en Irian Jaya, Indonésie. REINWARDTIA. 12(1): 1-94.

Purwanto Y. 2003. Etnobotani Masyarakat Tanimbar Kei, Maluku Tenggara. In Bahasa. Perhimpunan Masyarakat Etnobiologi Indonesia dan Lembaga Etnobiologi Indonesia.

Purwanto Y. 2009. Tempat Keramat Masyarakat Dani di Lembah Baliem, Papua antara Tradisi, Konservasi Sumber Daya Hayati dan Penguasaan Wilayah. dalam Soedjito et al. (2009) Situs Keramat Alami: Peran Budaya dalam Konservasi Kenakeragaman Hayati. In Bahasa. Yayasan Obor dan LIPI.

Purwanto Y and Munawaroh E. 2002. Quantitative Approach in the Ethno-medicinal Studies. Proceeding Symposium APINMAP II, Bogor, 8-10 August 2001. KEHATI Foundation, LIPI, APINMAP, UNESCO, and JICA. Bogor.

Purwanto Y and Mizuno K. 2011. Sustainable Management of Bio-Resources in Tropical Peat Swamp Forest. Proceeding of the Internationa Workshop. The Indonesian MAB-UNESCO National Committee, LIPI, G-COE in Search of Sustainable Humanosphere in Asia and Africa, RISH, CSEAS, and Kyoto University.

Purwanto Y, Walujo EB, Suryanto J, and Munawaroh E (Eds.). 2013. Strategi Adaptasi Pengelolaan Sumber Daya Alam Hayati Masyarakat Lokal di Cagar Biosfer Lore Lindu. In Bahasa. Pusat Penelitian Kependudukan. LIPI.

Purwanto Y, Saparita R, and Munawaroh E. 2011. Keanekaragaman jenis hasil hutan non kayu berpotensi ekonomi dan cara pengembangannya di Kabupaten Malinau. In Bahasa. Pusat Penelitian Biologi-LIPI, Balai Besar Pengembangan TTG-LIPI, Pusat Konservasi Tumbuhan dan Kebun RayaLIPI. LIPI Press.

Soedjito H. 2009. Tanah Ulen dan Konsep Situs Keramat Alami: Studi Kasus di Desa Setulang, Kabupaten Malinau, Kalimantan Timur. dalam Soedjito et al. (2009) Situs Keramat Alami: Peran Budaya dalam Konservasi Kenakeragaman Hayati. In Bahasa. Yayasan Obor dan LIPI. 
Soedjito H and Purwanto Y. 2003. Sacred sites of West Timor: Treasuries of Biodiversity and Cultural Heritage. In C. Lee and T. Schaaf (eds.). 2003. Proceedings of The International Workshop on the importance of sacred natural sites for biodiversity conservation. Kuming and Xishuangbanna Biosphere Reserve, People's Republic of China.

Soedjito H, Purwanto Y, and Sukara E (eds.). 2009. Situs Keramat Alami: Peran Budaya dalam Konservasi Keanekaragaman Hayati. Prosiding Lokakarya, Kebun Raya Cibodas, Cianjur, Jawa Barat, 30-31 Oktober 2007. In Bahasa. Yayasan Obor Indonesia, Komite Nasional MAB Indonesia, Lembaga Ilmu Pengetahuan Indonesia dan Conservation International Indonesia. Jakarta. 